\title{
Unveiling faculty conceptions of academic risk taking: a phenomenographic study
}

\section{Catarina Figueira*}

Cranfield School of Management, Cranfield University, Bedford, United Kingdom

Tel.: +44 (0)1234 754846; Email: catarina.figueira@ cranfield.ac.uk

Nicholas Theodorakopoulos

Aston Business School, Aston University, Birmingham, United Kingdom

Tel.: +44 (0)1212 043472; Email: n.theodorakopoulos@ aston.ac.uk

Giorgio Caselli

Cranfield School of Management, Cranfield University, Bedford, United Kingdom

Tel.: +44 (0)1234 754317; Email: giorgio.caselli@cranfield.ac.uk

\section{Acknowledgements}

We would like to thank Deirdre Anderson, Rosina Watson and participants at the Society for Research into Higher Education (SRHE) Annual Research Conference 2015 for their constructive comments and suggestions on earlier versions of this paper. We are also grateful to the interviewees for their valuable time and contribution to this study.

*Corresponding author. 


\title{
Unveiling faculty conceptions of academic risk taking: \\ a phenomenographic study
}

\begin{abstract}
Among recent developments in the field of higher education is the emergence of New Public Management and of what has been labelled as 'risk university'. The aim of this paper is to redress the lack of discussion over the role that risk taking plays in academic practice by exploring what faculty understand academic risk taking to be and how they enact this understanding in their tasks. Drawing on a phenomenographic perspective and semi-structured interviews with 20 faculty members from a high-profile UK university, we find that academic risk taking is experienced in four qualitatively different ways. Our results suggest that although academics engage in relatively similar endeavours, they exhibit various approaches to these endeavours due to their different conceptions of what constitutes academic risk taking. These findings have implications for the literature on identity construction and the debate over how the greater accountability of academic activity is affectively experienced.
\end{abstract}

Keywords: academic risk taking; academic work; identity construction; New Public Management; phenomenography; risk university

\section{Introduction}

Recent years have witnessed a growing interest in the changing nature of academic work (Archer 2008; Billot 2010; Ylijoki and Ursin 2013), following the emergence - in countries such as the UK, Australia and Finland - of what is commonly referred to as 'New Public Management' (Chandler, Barry, and Clark 2002; Deem 2004; Winter 2009). As Higher Education Institutions (HEIs) move towards a corporate managerialistic mode of operating (Churchman and King 2009), the core aspects of academic work are being reshaped around a culture of performance measurement, control and accountability (By, Diefenbach, and Klarner 2008). Among the latest institutional changes that best epitomise this 'audit explosion' (Strathern 1997, 309) is the emergence of the 'risk university' (Huber 2011, 4), that is, a risk-conscious HEI whose productivity and quality can and 
should be made quantifiable both within and outside itself (McWilliam 2007). In the UK higher education sector, the adoption of a risk-based approach as a benchmark for organisational actorhood became a regulatory requirement in 2001, when the Higher Education Funding Council for England (HEFCE) mandated universities to define their 'risk appetite' (HEFCE 2005) and evaluate the reputational impact of key risks (Power et al. 2009).

Although risk as a matter of organisational concern is gradually pervading the field of higher education (Hommel and King 2013), the concept of risk from an individual academic's viewpoint remains relatively underdeveloped (Gresty et al. 2013). To our knowledge, there has been virtually no research into what faculty members understand academic risk taking to be and how they enact this understanding in their practice. This is surprising, since a great deal of decision making involves selecting among alternatives that vary in terms of expected outcomes and perceived probabilities of achieving these outcomes (Krueger and Dickson 1994). Furthermore, we are not aware of any attempt to explore the extent to which the increasingly restrictive and controlled context within which academics are currently working affects their perceptions of what constitutes risk taking in their tasks. Such a void is at odds with the evidence put forward by a recent strand of the literature, which suggests that the greater risk consciousness permeating the contemporary university acts both to constrain and to enable what academic staff pay attention to (McWilliam 2007).

Against this background, the aim of this paper is to redress the lack of discussion over what academic risk taking seems to be and unpack the qualitatively different ways in which faculty experience academic risk taking. In doing so, this study makes a threefold contribution. First, by unveiling academic staff conceptions of risk taking and their intentions in engaging in risk behaviour, our findings add to the growing 
understanding of the reasons behind different approaches to academic work. Second, we provide novel insights into issues that lie at the point of tension between individual perceptions and institutional expectations, thereby responding to calls for further studies on how the greater measurement and accountability of academic activity is affectively experienced (Davies and Petersen 2005). The latter point has implications for identity (re)construction among academics (Knights and Clarke 2014). Third, our contribution opens up a promising research avenue into how the lived experience of risk taking by academics is linked to student learning and development.

\section{Literature review}

Over the last two decades, a substantial body of literature has developed examining how faculty conceptions of the two main conventional elements of academic practice (i.e. teaching and research) influence the way they approach these activities (Brew 2001; Franke and Arvidsson 2011; Samuelowicz and Bain 1992). Although individual contributions have remained somewhat fragmented, this literature shares the assumption that understanding the meaning - or range of meanings - of teaching and research (including research supervision) held by faculty is key in explaining the variety of ways in which they engage in their practice. Nowadays, there is considerable agreement over the role of academics' conceptions of teaching, along with aspects such as the teaching context (Lindblom-Ylänne 2006), academic leadership (Ramsden et al. 2007) and emotions (Trigwell 2012), in shaping their approaches to teaching (Åkerlind 2004; Prosser and Trigwell 1999; Samuelowicz and Bain 1992). Similarly, in a growing strand of the literature, there are related variations in faculty lived experiences of research and being a researcher as to the different ways academics approach research (Åkerlind 2008; Brew 2001) as well as supervision (Bills 2004; Kiley and Mullins 2005). More recently, a handful of studies have provided evidence suggesting that differences in academics' 
approaches to doctoral student supervision are partly explained by their qualitatively different understandings of what constitutes research supervision (Franke and Arvidsson 2011; Lee 2008; Wright, Murray, and Geale 2007). Interestingly, support is also found for the existence of different ways of experiencing supervision as teaching among higher degree research supervisors (Bruce and Stoodley 2013).

Notwithstanding the important contribution of this strand of the literature to enhancing our understanding of academic practice, it is only recently that researchers have begun to acknowledge the role of risk in academic staff behaviour (Zoller, Zimmerling, and Boutellier 2014). This paucity of evidence is startling in light of extant decision-making theories, which postulate that individuals assess the probability and value of alternative outcomes before choosing how to behave (March and Shapira 1992). Risk taking is generally described as a decision situation characterised by 'a lack of certainty and the prospect of loss or failure' (Kogan and Wallach 1967, 113). The foundation for theories of risk taking was laid in the 1940s through the influential work of von Neumann and Morgenstern (1944), who suggested that (rational) individuals make decisions among available courses of action with the aim of maximising their expected utility. Around the same time, Lewin et al. (1944) proposed goal setting as an alternative decision-making process. The main idea underlying this approach is that people's preferences for relatively higher goals depend on the perceived balance between the probability and value of success. Drawing on the work by Lewin et al. (1944), Rotter (1954) presented a model for explaining social behaviours in which the decision-making criterion is formulated in terms of anticipated payoff.

With time, the overall validity of the expected utility framework has been called into question on the ground of its neglect of individual differences as well as situational aspects. On this front, two important contributions are represented by Atkinson's (1957) 
need for achievement theory and Kahneman and Tversky's (1979) prospect theory. While Atkinson (1957) suggested that individuals' attitudes towards risk are the outcome of their desired need for success, Kahneman and Tversky (1979) posited that risk taking is affected by the (either positive or negative) way in which a problem is framed. Moreover, Sitkin and Weingart (1995) reviewed the literature on the factors predicting risk behaviour and provided empirical support for a model in which risk propensity and risk perception mediate the effects of outcome history and problem framing on decisions entailing risk.

Among the first attempts to apply theories of risk taking to the educational context is the work by Clifford and colleagues (Clifford 1991; Clifford and Chou 1991; Clifford et al. 1990). Drawing on studies from the fields of economics and psychology, Clifford (1991, 276-277) normatively defined 'academic risk taking' as 'student selection of school achievement tasks that vary in probability of success and are accompanied by feedback or the expectation of feedback'. While arguing that moderate risk taking (i.e. the selection of tasks with at least .50 probability of success) offers beneficial outcomes in terms of learning and effort exertion, Clifford (1991) called for the need to transform educational activities into risk-taking tasks and create classroom environments conducive to greater risk taking on the part of students.

Whilst it is acknowledged that consideration of risk from the student perspective 'could provide additional teaching opportunities and student learning benefits' (Gresty et al. 2013, 571), an understanding of what academic risk taking means to faculty members (i.e. what academics deem as risky in the endeavours related to their practice), and how they enact these meanings in their practice, is absent from the literature. We aim to address this gap by exploring the conceptions of risk taking among academic staff and the extent to which these conceptions influence the courses of action they pursue in their 
practice (i.e. what they do in terms of teaching and research). Therefore, the key research questions are as follows:

(1) What are the qualitatively different ways in which faculty conceive of risk taking within their work domains?

(2) How do faculty conceptions of academic risk taking affect the way they approach teaching and research?

\section{Methodology}

In line with the purpose of searching for variation in faculty understandings of academic risk taking, this study adopts a phenomenographic research approach (Marton and Säljö 1976). Originally developed in the field of Swedish education during the 1970s, this approach aims at describing the 'qualitatively different ways in which people perceive and understand their reality' (Marton 1981, 177). Departing from the much older philosophical perspective of phenomenology, the distinguishing feature of phenomenography is its focus on the lived experience of a phenomenon (Ashworth and Lucas 2000). In the language of phenomenographic research, the different ways people make sense of their experiences are labelled as conceptions (Marton and Booth 1997). Throughout this paper, a conception is defined as the qualitative way in which academics construe and enact risk taking within their practice. These variations in understandings are organised into categories of description, which are the researcher's own interpretation of the data based on the qualitatively different ways in which participants experience an aspect of reality (Sandberg 1997). From a phenomenographic perspective, faculty understandings of risk taking within their work domains may be categorised according to the awareness shown with respect to certain dimensions of variation (Åkerlind 2003), reflecting the interviewee's perception of the potential for variation in key aspects of 
academic risk taking (Marton and Booth 1997). Each category of description represents a holistic understanding of academic risk taking and consists of a referential component, in which the underlying meaning is gauged, as well as a structural component, where the structure of awareness underpinning the participant's lived experience is established (Marton, Dall'Alba, and Beaty 1993). In turn, the structural component of each category is constituted by an internal horizon - the focus of the participant's awareness (Pham, Bruce, and Stoodley 2005) - and an external horizon - 'that part of the world beyond which participants, who are looking at the world in a particular way, do not see' (Bruce, Pham, and Stoodley 2004, 224). Finally, the inter-relationships between the categories of description are represented in an outcome space of experience and understanding (Francis 1996), which illustrates the logical ordering of the categories based on their referential and structural components (Marton, Dall'Alba, and Beaty 1993). Therefore, the outcome space developed in this study represents faculty members' collective awareness of what constitutes risk taking in their practice.

\section{Sample selection}

To reduce extraneous variation and understand 'what the case might be' (Gomm, Hammersley, and Foster 2000), we focused on a single, high-profile university. The university is considered as an instrumental case of an institution that, while being research-led, places particular emphasis on the learning experience and satisfaction of its students. As the epistemological stance of phenomenography suggests (Marton 1995), within-case sample selection was driven by the need to ensure the maximum possible variation in conceptions. This is consistent with the literature on risk taking, which submits that 'individuals can respond to the same socio-structural and natural/material context in different ways' (Zinn 2015, 103). A purposive sample of 20 academics on teaching and research appointments was selected. The number of faculty included in the 
sample was based on the results of previous phenomenographic studies, which indicate that variation in experiencing a phenomenon tends to reach saturation at around 20 participants (Sandberg 2000; Shreeve 2010; Wright, Murray, and Geale 2007). Interviewees represented a mix of genders, language backgrounds, tenure, disciplines and positions within the university hierarchy. Specifically, 11 faculty members were male and 9 were female, while the average time spent in academia was about 16 years. Concerning their seniority, the distribution is as follows: 2 research fellows, 2 lecturers, 9 senior lecturers, 4 readers and 3 professors. Disciplinary interests were spread over cognate domains such as applied psychology, corporate finance and mathematical modelling. In addition, the sample included academics with various degrees of experience in terms of publications and research grants, alongside doctoral student supervision.

\section{Data collection}

To encourage an open and deep account of the participant's lived experience of risk taking in their practice (Booth 1997), data were collected through semi-structured, in-depth interviews, which were undertaken at the participants' workplace. Each interview lasted around one hour and was recorded, transcribed verbatim, and content-checked for accuracy with the interviewee. In an attempt to establish a community of interpretation between the researcher and participants (Apel 1972), the interviews started with a discussion of the purpose of the study as well as a series of background questions. To capture both the referential (what) and structural (how) aspects of conceptions (Marton, Dall'Alba, and Beaty 1993), interviewees were asked to elaborate on what academic risk taking meant to them, how they enacted it in their practice and why they did things in a certain way. As virtually no study exists on conceptions of academic risk taking among faculty, the approach to data collection was deliberately broad and questions were aimed at orienting participants towards the phenomenon, while allowing them to structure it 
based on their own experience. Therefore, the interviews centred primarily around examples of academic risk taking volunteered by participants, with follow-up questions such as, 'What do you mean by that?' or 'Can you tell me a bit more about that?' in order to assess the meanings held by interviewees and to probe further elaboration of the topics.

\section{Data analysis}

The starting point of our analysis was the development of a general grasp of faculty conceptions of academic risk taking. In line with the suggestions of Ashworth and Lucas (2000), we endeavoured to reflect the emphases and emotions of participants by listening to the recordings several times instead of analysing directly from the text. Each transcript was then read several times and interviewees were tentatively classified into different groups according to their understandings of academic risk taking. Since the start of the analysis, we tried to ensure that our findings were the product of the participant's lived experience by being reflexive (Clegg and Stevenson 2013), holding back our own presumptions and continuously checking that our interpretations were grounded in the text. Once we became familiar with the entire set of interviews, we moved on to systematically explore what each faculty member conceived of as academic risk taking. The focus of this second step was on capturing the referential aspect associated with each conception in relation to the overall context in which a given statement was made. After searching for variation in meanings among participants, we followed a similar approach to explore the structural aspect of conceptions. During this phase, we re-read each transcript with the purpose of discerning the basic meaning structure characterising the qualitatively different ways of understanding academic risk taking. Finally, we analysed the transcripts once again, this time alternating between what faculty perceived as risktaking behaviour within their work and how they made sense of that behaviour. At this stage, each transcript was simultaneously checked against 'the what and how' of 
conceptions with the aim of arriving at a stable set of categories of description (Miles and Huberman 1994). This iterative process continued until we were in agreement that we had established the most faithful interpretation of each participant's lived experience and no further regrouping was required. The quotes presented in the following section are illustrative of the points made by the participants and represent their sentiments as to risk taking in their practice.

\section{Findings}

In our interpretation, four categories of description - which we labelled as Category 1 through to 4 - emerged from the interview transcripts. These focus on the lived experience of academic risk taking as 'experimenting with things', 'being intellectually opportunistic', 'challenging conventional wisdom' and 'doing what you feel is right'. The qualitatively different ways of seeing academic risk taking among faculty can be organised into an outcome space (Table 1), which represents the logical relationships between the categories according to their referential and structural components (Marton, Dall'Alba, and Beaty 1993). In line with previous phenomenographic research (Brew 2001; Bruce, Pham, and Stoodley 2004; Wright, Murray, and Geale 2007), the outcome space developed in this study should not be interpreted as a hierarchy of increasing comprehensiveness of conceptions, but rather as a widening of awareness across the categories (Marton and Booth 1997). The variation along the two structural components of each category of description (i.e. the external and internal horizons) can be gauged in Table 1 by progressing down the rows. As one moves from Category 1 to 4 , the external horizon (Bruce, Pham, and Stoodley 2004, 224) expands progressively from the individual (Category 1) to the university community (Categories 2 and 3) to society at large (Category 4). Differences are also found in relation to the internal horizon (Pham, Bruce, and Stoodley 2005), since descriptions foreground knowledge and skills (Category 
1), capabilities and reputation (Category 2), student learning and disciplinary advancement (Category 3), and contribution to the common good (Category 4). At one end of the spectrum, the statements in Category 1 indicate that the knowledge and skills possessed by the individual academic are central in awareness, whereas the progress of the discipline is generally considered by faculty as less relevant to their lived experience of academic risk taking. At the other end of the spectrum, descriptions included in Category 4 are characterised by a shift in focus from personal skills and capabilities to the contribution to society, suggesting that academics' awareness is directed towards the benefits for a larger social group.

The analysis of the interview transcripts reveals that the qualitatively different ways of conceiving of risk taking within academic work tend to vary along four major dimensions:

- how participants explain the motivations behind their risk behaviours (determinants);

- what they perceive the consequences of their actions to be (outcomes);

- the extent to which the combination of determinants and anticipated outcomes is translated into risk management practices (coping mechanisms); and

- how the interplay between determinants, outcomes and coping mechanisms alongside the underlying risk behaviours - is affectively experienced (feelings).

Although the set of categories may be stable and generalisable across situations (Marton 1981), there is evidence that an individual may bring certain elements of his/her lived experience into the foreground and push others to the background of awareness, depending on the context. While most of the interviewees are associated with two or three categories, none of them appear to span all four. The variation in faculty ways of 
understanding academic risk taking is elaborated below through the use of illustrative quotations (the first number in the reference attached to each quotation corresponds to the individual academic, whereas the second number indicates the transcript page).

[Insert Table 1 about here]

\section{Category 1: academic risk taking as 'experimenting with things'}

In conceiving of academic risk taking as 'experimenting with things', the meanings embedded in the first category refer to courses of action that are perceived to go beyond what faculty are familiar with. Examples include the application of new teaching methods, the start of new research projects and the intake of new doctoral students.

I try new things in the classroom and I try new case studies, I might write new... because of the work that I do... we do a lot of doing in the classroom, because it's mainly quantitative... So, every time you try something new at some level, you take a risk. (A11.2)

I suppose it is the willingness to do new courses, start new courses or even in class explore new methods that you're not used to... you know... innovation for yourself. (A16.2)

Interviewees holding this conception construe academic risk taking around their perceived knowledge and skills, suggesting that the individual is central to the focus of awareness. Although the context within which faculty are working is viewed as partly influencing their behaviours, the statements in this category generally point to individual traits as the main determinant of academic risk taking.

When calls for proposals come in... having the courage... to say... 'Yes, I'll take this' and there is an example of a project I've been working on recently that wasn't squarely in my area of interest, but the project came in and... (A12.4) 
I think there's something about courage, about the need for courage. (A14.3)

Academic risk taking is experienced as a process whereby faculty members can not only extend their knowledge and skills, but also fulfil the requirements of their job. At the same time, the interviewees' descriptions highlight that the engagement in new and less familiar activities might hinder their career progression (e.g. due to lower student satisfaction).

Certainly, from a teaching point of view, it's about improving what I do... from a writing bids and writing publications point of view, it's part of the job... if you don't take them, you don't move forward. (A11.5)

You've got to take risk to learn... This way I explore, I learn... even though it's risky... It's risky in terms of... students' feedback, very much so... I think I suffer for it. (A16.4)

The benefit is, when it works, you've extended your repertoire. The drawback is first of all you could fall flat on your face... The other drawback is it takes an immense amount of time doing the risk mitigation. (A17.4)

The mechanisms adopted to cope with the identified risks encompass investing time in preparation, as well as collaborating with and seeking advice from more experienced colleagues. Feelings associated with academic risk taking in teaching, learning and research activities vary from a sense of achievement about the learning process to anxiety over possibly failing to meet the requirements.

I'm very nervous, but I'm also conscious and aware that I have to take the risk. I cannot just stay and do the same things that I'm doing at the moment. (A4.7)

I wouldn't say I found it particularly comfortable, but it is a very nice feeling when you get money awarded to do some research or you get a paper published. (A11.7) 


\section{Category 2: academic risk taking as 'being intellectually opportunistic'}

In the second category, which characterises academic risk taking as 'being intellectually opportunistic', interviewees stress the need for individual academics to find a 'market niche' (A5.2) within which they can develop their capabilities and build their reputation. In defining academic risk taking as 'intellectual entrepreneurship', the following quotation makes an interesting analogy between an academic and an entrepreneur.

It's finding that niche, where you're able to make your special, unique contribution. For me, that's very much what academic, or intellectual entrepreneurship, is about and in that sense, that's one way and I think the core essence of, if you like, risk taking... I do think it is about really having a judgment as to where the opportunities are and then going for it. Just as an entrepreneur would take that sort of risks in business settings, so too should an academic. (A5.2)

Departing from the first conception, the statements in this category indicate that academic risk taking may be the result of a combination of personality traits and external influences, predominantly institutional forces. This seems to suggest that, while interviewees may adapt their risk behaviours to the changing university context, this process occurs within the boundaries of their holistic understanding of what constitutes academic risk taking.

The motivator of taking risk is... because you believe... if it comes to the paper... that you've got something there and sometimes it is a bit of instinct that you need to follow in research... on the other hand, with the climate being more competitive, less resources, universities needing research money, there's a pressure in terms of the REF... I think people have become more creative and maybe that brings risk with it. (A18.8)

In viewing risk taking as a prerequisite for becoming successful academics, interviewees typically emphasise the benefits for career advancement that may stem from academic risk taking. Besides allowing to establish oneself as a 'thought leader' (A5.8) in a particular area, these encompass more extrinsic benefits such as advancing the discipline 
and contributing to knowledge. Overall, the existence of extrinsic benefits alongside more individualistic goals points to an expansion of awareness from the individual academic to the university community as we move from Category 1 to Category 2. Notwithstanding this, student and societal needs appear to be absent from the focus of awareness.

The risk of failing to take that kind of risk is potentially working in an overtraded market, where there are hundreds, if not thousands, of people doing the same research that you're doing. (A5.3)

It's, I guess, progressing, making contribution and... adding value to your discipline and pushing the boundaries. (A18.8)

Faculty possessing this conception observe that their ability to identify opportunities aligned with their passion has increased over the years as they gained more experience. Moreover, they point to a number of coping mechanisms that are put into practice in an attempt to mitigate the risk of choosing the wrong course of action.

For the individual academic and particularly the young, emerging, early career academic... it makes a huge difference if one has a mentor or more than one mentor... it may mitigate the academic taking courses of action which are going to lead nowhere. (A5.4)

A small paper went to a small conference, got some feedback and actually the initial one was presented here in a seminar, which proved very useful. (A18.4)

In this category, academic risk taking involves feelings varying from self-fulfilment to a sense of insecurity, depending on the extent to which the decisions taken are perceived to be enabling the establishment of oneself in the field and the progress of the discipline.

\section{Category 3: academic risk taking as 'challenging conventional wisdom'}

Descriptions of academic risk taking as 'challenging conventional wisdom' underscore 
behaviours that question widely held assumptions about the nature of reality. While viewing the departure from the status quo as key in research and teaching, interviewees holding this conception feel that their actions may upset entrenched expectations and increase the risk of failure.

An example I can give you is whether you want to engage in an [research] area... which is beyond your comfort zone... And some people... tend to move towards another kind of direction, even though they are not very comfortable with that, OK? So, this is risk taking. (A2.1-2)

I need to challenge students and sometimes I do this in a very direct way in order to at least ask the students to free their mind and think beyond conventional wisdom... in order to just make them think... that there's something else out there. (A3.4)

The quotes in this category share with the previous ones the intrinsic nature of the drivers explaining risk behaviour (self-efficacy and immediate rewards). However, there is evidence of a shift from an almost exclusive focus on the individual academic to a greater concern for the implications that risk taking may have for student learning, the advancement of the discipline and the organisational reputation. This evidence suggests a widening of the external horizon compared to Categories 1 and 2.

In research, maybe you'll be researching new things or making new links across different areas that haven't been made before... In teaching, maybe the students are getting more interesting stuff. (A15.8)

In terms of research... if you're willing to take some risk and to go... beyond your comfort zone, then you get involved with different kinds of projects which can be very beneficial [for the university]. (A2.6)

With the research project you often have an idea that you want to get across, but... there's again the expectations of a client. So, do you go with these expectations or do you contradict their expectations, saying 'But we could do it differently'? (A3.4) 
Whilst academic risk taking in teaching and research is sometimes accompanied by feelings of frustration, anxiety and fear, interviewees are generally able to devise risk management practices that allow them to successfully 'play the game' (A2.11). These include the use of rhetoric, the development of a better understanding of the student population and the reflection over how ideas that break with existing logics may be introduced.

Academia nowadays is predominantly mainstream, so for somebody who is heterodox, then he has to... just try and develop some kind of rhetoric, of a discourse. (A2.12)

It's thinking through the process of how you introduce this, thinking about the particular population, thinking about the different learning types, thinking about how you structure the learning process, how you measure it, how you evaluate it and so forth. (A15.12)

You try to introduce [an idea which is different from the mainstream] slowly into different, not in one paper. (A20.2)

\section{Category 4: academic risk taking as 'doing what you feel is right'}

The fourth category concerns descriptions that relate academic risk taking with the pursuit of personal ideals and values, such as the solution of real-world problems, the advancement of a social cause or the contribution to the good of society at large. In construing academic risk taking as 'doing what you feel is right', the quotations in this category emphasise the tensions between what faculty perceive as their professional identity and the institutional requirements - the 'rules of the game' (A19.1) -underlying the context within which they are working.

[Academic risk taking means] being brave, being outspoken about what you think and you believe is right... Obviously, going for the good of society, because you're taking the risk for the common good, not just for yourself, and, so, I associate risk 
taking for the good of... the discipline, society or someone that is not you and to progress the knowledge in the field or to help us all get better... (A10.1)

I like to engage with practitioners... that in some ways is counterintuitive by the rules of the game. The institutional forces make it very clear that if you want to play in the academic circles... you have to basically 'publish or perish'. (A19.1-2)

Notwithstanding the perceived conflict between personal beliefs and institutional forces, the anticipated benefits act as a key motivating factor behind academic risk taking. Moving away from the previous conceptions, this category is distinguished by an altruistic focus on the benefits to a wider social group alongside more intrinsic reasons. Conversely, the skills and capabilities possessed by faculty members are not in the focus of awareness. Interestingly, the negative outcomes that might result from engaging in relatively risky endeavours do not prevent some of the interviewees from following their ideals.

I understand the risks and I'm willing to accept them and then you would be talking about the risks in relation to career progression. (A7.9)

If you play it safe and you say... 'I'm just going to go for the three star, do the survey, meet the requirements and get it through...' that for me would be going against my beliefs, but... I would be playing the game and... I would be very good in my career. (A10.4-5)

Other statements in this category reveal a desire on the part of faculty to learn to cope with the changing institutional context which privileges certain types of behaviour. This suggests a continuous process of identity construction and deconstruction, involving significant emotional effort as well as self-questioning. Academic risk taking as 'doing what you feel is right' is experienced through feelings that range from passion and a sense of reward to scepticism, helplessness and demotivation. 
It is much more rewarding to do research that you feel will have some benefits at the end. (A13.3)

In some ways it adds credibility and you feel more impactful... I feel more like where I should be... a bit like a medical doctor. Many of them are not only currently working with their customers, meaning the patients, but they're also directly doing research at the same time. (A19.13)

I do take the risks, because I'm passionate about the job, but I don't know if it's wise in this current environment. I think I'm still a bit romantic about the idea of being an academic and really doing good for the society. (A10.10)

\section{Discussion and conclusions}

This paper set out to redress the lack of debate over the role that risk taking plays in academic practice by uncovering the qualitatively different ways in which faculty experience academic risk taking. By beginning to explore a complex domain of higher education that has hitherto been largely overlooked, this study makes a significant contribution by providing a conceptual basis for understanding what academic risk taking means to faculty and how such meanings may be enacted in professional practice. The variation in faculty members' lived experiences of academic risk taking as found in this study is summarised in Table 2. The key elements of the categories of description are reported in the columns, while a broadening of awareness is illustrated in the rows of the table. Orientation corresponds to the outer limits of awareness (i.e. the external horizon). Content denotes what academics perceive as the core essence of risk taking in their work domains. Intention represents the goal that faculty attempt to achieve when engaging in risk behaviours. Strategy refers to the way in which academic risk taking is enacted in their everyday tasks. Therefore, our findings indicate that, if the individual academic is central in awareness, faculty may perceive academic risk taking as venturing into unfamiliar areas with the aim of improving their knowledge, skills and competencies 
relating to their professional activities. In instances where academics adopt an orientation towards the university community, academic risk taking is associated with the search for new opportunities and is enacted by departing from the status quo to enhance academic standing in the wider community. Lastly, when societal needs are the focus of awareness, faculty members may engage in risk taking behaviours by following their personal ideals and values in an attempt to contribute to the common good, even if their actions are perceived to go against institutional forces.

\section{[Insert Table 2 about here]}

Our results suggest that faculty understandings of what constitutes risk taking within academic practice have a bearing on the way they approach their teaching and research. First and foremost, the meanings that academics give to risk taking draw the boundaries of human agency by affecting the courses of action pursued and, by implication, the academic professional practice. Participants in our study point to a number of conduct patterns that may not be enacted if they are deemed inappropriate or, as described by the interviewees, 'too risky'. These include entering a political argument, breaching personal or institutional values, or committing to research avenues that are perceived as not meaningful. Furthermore, our analysis reveals that the ways in which faculty conceive of academic risk taking indeed affect what they pay attention to (McWilliam 2007). While fundamental differences exist with respect to how individual meanings are enacted, perceptions about what is risky in academic endeavours result in the adoption of a range of coping mechanisms aimed at mitigating the identified risks. Moreover, the findings indicate that relatively similar tasks may be affectively experienced by faculty in a variety of ways depending on how they construe academic risk taking. Particularly noteworthy is the evidence that conceptions held by academic staff are being shaped by the increasingly managerial context within which they are 
working, which sometimes causes feelings of self-questioning, helplessness and demotivation. On this front, our results shed some light on the nature characterising some of the identity tensions experienced by academics (Knights and Clarke 2014), thereby adding to the growing literature on how faculty are seeking to manage their changing identities in light of the revised accountability requirements (Billot 2010; Winter 2009; Ylijoki and Ursin 2013).

The framework provided in this paper has a number of implications for academic practice. A major lesson is that there may be benefits in gaining greater awareness of and being sensitive to the qualitatively different ways in which faculty experience academic risk taking. By offering a typology and a lexicon for expressing variation in understandings, the conceptions unveiled in this research may encourage individuals to question the assumptions underpinning their meanings and reflect on the reasons behind their risk-taking behaviours. A more open dialogue among academic staff may also allow them to share some of the tensions that lie at the root of their lived experiences and learn about possible mechanisms to cope with these tensions. Furthermore, as the ways of construing academic risk taking are ultimately linked to conduct, the framework may represent a useful tool for discussion during the recruitment and performance appraisal of academic staff. In a similar vein, importantly, our findings suggest that the potential to improve how academics teach, undertake research or supervise students hinges on their conceptions of academic risk taking. As a result, training and development activities should provide faculty with a safe space for reflecting what academic risk taking means to them and how they enact these meanings in their practice. At the same time, novel insights into how academics make sense of risk taking in their professional practice in the face of a rapidly changing higher education sector can improve our understanding of how HEIs may respond to wide-ranging and deep institutional change. For this reason, the 
framework developed in this paper can be used as a springboard for future qualitative and quantitative studies dealing with individual risk taking in HEIs at a time of unprecedented sector reform. Such studies could take several directions. These are outlined in the following section.

\section{Avenues for future research}

Our hope is that this paper will contribute to new research avenues into how the qualitatively different ways in which faculty construe academic risk taking relate to their conceptions of and approaches to teaching and research. Future studies could explore the extent to which conceptions of academic risk taking change depending on the organisational culture, work organisation and human resource practices, including differences in teaching loads, norms and expectations about research output and promotion criteria. Second, consistent with the literature around risk taking (Zinn 2015), our results suggest that what academics perceive as their professional identity has a bearing on how they think of risk taking within their activities. A fruitful line of enquiry would be to extend the findings of this paper by elucidating how various academic identities underlie the different ways of experiencing academic risk taking. Third, further work is needed to gain deeper insight into how conceptions of academic risk taking among faculty shape professional practice. Our framework is developed within the context of a primarily research-led UK university. Particularly useful would be studies that make international comparisons, allowing for institutional variation, and adopt a range of methodological approaches. We envisage that such lines of enquiry could further

refine the advanced typology, confirm the efficacy of coping mechanisms identified in this paper and elucidate the link between faculty understandings of academic risk taking, professional conduct and various performance-related outcomes, at different levels. The latter include both teaching and research-related outcomes; for instance, learning 
experience, student achievement and satisfaction, publications, research grants, as well as impact on various domains, such as academia, practice and policy making.

\section{References}

Åkerlind, G. S. 2003. "Growing and Developing as a University Teacher: Variation in Meaning." Studies in Higher Education 28 (4): 375-90.

Åkerlind, G. S. 2004. “A New Dimension to Understanding University Teaching." Teaching in Higher Education 9 (3): 363-75.

Åkerlind, G. S. 2008. "An Academic Perspective on Research and Being a Researcher: An Integration of the Literature." Studies in Higher Education 33 (1): 17-31.

Apel, K. 1972. "The A Priori of Communication and the Foundation of the Humanities." Man and World 5 (1): 3-37.

Archer, L. 2008. "Younger Academics' Constructions of 'Authenticity', 'Success' and Professional Identity.” Studies in Higher Education 33 (4): 385-403.

Ashworth, P., and U. Lucas. 2000. "Achieving Empathy and Engagement: A Practical Approach to the Design, Conduct and Reporting of Phenomenographic Research." Studies in Higher Education 25 (3): 295-308.

Atkinson, J. W. 1957. "Motivational Determinants of Risk-Taking Behavior." Psychological Review 64 (6): 359-72.

Billot, J. 2010. "The Imagined and the Real: Identifying Tensions for Academic Identity." Higher Education Research and Development 29 (6): 709-21.

Bills, D. 2004. "Supervisors' Conceptions of Research and the Implications for Supervisor Development." International Journal for Academic Development 9 (1): 85-97.

Booth, S. 1997. "On Phenomenography, Learning and Teaching." Higher Education Research and Development 16 (2): 135-58.

Brew, A. 2001. "Conceptions of Research: A Phenomenographic Study." Studies in Higher Education 26 (3): 271-85.

Bruce, C., B. Pham, and I. Stoodley. 2004. "Constituting the Significance and Value of Research: Views from Information Technology Academics and Industry Professionals.” Studies in Higher Education 29 (2): 219-38.

Bruce, C., and I. Stoodley. 2013. "Experiencing Higher Degree Research Supervision as Teaching." Studies in Higher Education 38 (2): 226-41.

By, R. T., T. Diefenbach, and P. Klarner. 2008. "Getting Organizational Change Right in Public Services: The Case of European Higher Education." Journal of Change Management 8 (1): 21-35. 
Chandler, J., J. Barry, and H. Clark. 2002. "Stressing Academe: The Wear and Tear of the New Public Management.” Human Relations 55 (9): 1051-69.

Churchman, D., and S. King. 2009. "Academic Practice in Transition: Hidden Stories of Academic Identities." Teaching in Higher Education 14 (5): 507-16.

Clegg, S., and J. Stevenson. 2013. "The Interview Reconsidered: Context, Genre, Reflexivity and Interpretation in Sociological Approaches to Interviews in Higher Education Research.” Higher Education Research and Development 32 (1): 5-16.

Clifford, M. M. 1991. "Risk Taking: Theoretical, Empirical, and Educational Considerations." Educational Psychologist 26 (3-4): 263-97.

Clifford, M. M., and F.-C. Chou. 1991. "Effects of Payoff and Task Context on Academic Risk Taking." Journal of Educational Psychology 83 (4): 499-507.

Clifford, M. M., F.-C. Chou, K.-N. Mao, W. Y. Lan, and S.-Y. Kuo. 1990. “Academic Risk Taking, Development, and External Constraint." Journal of Experimental Education 59 (1): 45-64.

Davies, B., and E. B. Petersen. 2005. "Intellectual Workers (Un)Doing Neoliberal Discourse." Critical Psychology 13 (1): 32-54.

Deem, R. 2004. "The Knowledge Worker, the Manager-Academic and the Contemporary UK University: New and Old Forms of Public Management." Financial Accountability and Management 20 (2): 107-28.

Francis, H. 1996. “Advancing Phenomenography: Questions of Method.” In Reflections on Phenomenography: Toward a Methodology? Edited by G. Dall’Alba, and B. Hasselgren, 35-47. Göteborg: Göteborg Studies in Educational Sciences.

Franke, A., and B. Arvidsson. 2011. "Research Supervisors' Different Ways of Experiencing Supervision of Doctoral Students." Studies in Higher Education 36 (1): 7-19.

Gomm, R., M. Hammersley, and P. Foster. 2000. "Case Study and Generalisation.” In Case Study Method, edited by R. Gomm, M. Hammersley, and P. Foster, 98-115. London: Sage.

Gresty, K. A., W. Pan, T. Heffernan, and A. Edwards-Jones. 2013. "Research-Informed Teaching from a Risk Perspective." Teaching in Higher Education 18 (5): 570-85.

HEFCE. 2005. Risk Management in Higher Education: A Guide to Good Practice. Bristol: HEFCE. http://www.hefce.ac.uk/pubs/hefce/2005/05_11/.

Hommel, U., and R. King. 2013. "The Emergence of Risk-Based Regulation in Higher Education: Relevance for Entrepreneurial Risk Taking by Business Schools." Journal of Management Development 32 (5): 537-47.

Huber, M. 2011. The Risk University: Risk Identification at Higher Education Institutions in England. London: London School of Economics and Political Science. http://eprints.lse.ac.uk/38891/. 
Kahneman, D., and A. Tversky. 1979. "Prospect Theory: An Analysis of Decision under Risk." Econometrica 47 (2): 263-92.

Kiley, M., and G. Mullins. 2005. "Supervisors' Conceptions of Research: What Are They?" Scandinavian Journal of Educational Research 49 (3): 245-62.

Knights, D., and C. A. Clarke. 2014. "It's a Bittersweet Symphony, this Life: Fragile Academic Selves and Insecure Identities at Work.” Organization Studies 35 (3): 335-57.

Kogan, N., and M. A. Wallach. 1967. "Risk Taking as a Function of the Situation, the Person and the Group." In New Directions in Psychology, edited by G. Mandler, P. Mussen, N. Kogan, and M. A. Wallach, 111-278. New York: Holt, Rinehart and Winston.

Krueger, Jr., N., and P. R. Dickson. 1994. "How Believing in Ourselves Increases Risk Taking: Perceived Self-Efficacy and Opportunity Recognition.” Decision Sciences 25 (3): 385400.

Lee, A. 2008. "How Are Doctoral Students Supervised? Concepts of Doctoral Research Supervision." Studies in Higher Education 33 (3): 267-81.

Lewin, K., T. Dembo, L. Festinger, and P. S. Sears. 1944. "Level of Aspiration.” In Personality and the Behavior Disorders, edited by J. M. Hunt, 333-78. New York: Ronald Press.

Lindblom-Ylänne, S., K. Trigwell, A. Nevgi, and P. Ashwin. 2006. "How Approaches to Teaching Are Affected by Discipline and Teaching Context." Studies in Higher Education 31 (3): 285-98.

March, J. G., and Z. Shapira. 1992. "Variable Risk Preferences and the Focus of Attention." Psychological Review 99 (1): 172-83.

Marton, F. 1981. "Phenomenography: Describing Conceptions of the World around Us." Instructional Science 10 (2): 177-200.

Marton, F. 1995. "On Non-Verbal Learning: Level of Processing and Level of Outcome." Scandinavian Journal of Psychology 16: 273-79.

Marton, F., and S. Booth. 1997. Learning and Awareness. Mahwah: Erlbaum.

Marton, F., G. Dall'Alba, and E. Beaty. 1993. “Conceptions of Learning.” International Journal of Educational Research 19 (3): 277-300.

Marton, F., and R. Säljö. 1976. "On Qualitative Differences in Learning: Outcome and Process." British Journal of Educational Psychology 46 (1): 4-11.

McWilliam, E. 2007. "Managing 'Nearly Reasonable' Risk in the Contemporary University." Studies in Higher Education 32 (3): 311-21.

Miles, M. B., and A. M. Huberman. 1994. Qualitative Data Analysis. 2nd ed. Thousand Oaks: Sage.

Pham, B., C. Bruce, and I. Stoodley. 2005. "Constituting Information Technology Research: The Experience of IT Researchers." Higher Education Research and Development 24 (3): 215-32. 
Power, M., T. Scheytt, K. Soin, and K. Sahlin. 2009. "Reputational Risk as a Logic of Organizing in Late Modernity." Organization Studies 30 (2-3): 301-24.

Prosser, M., and K. Trigwell. 1999. Understanding Learning and Teaching: The Experience in Higher Education. Buckingham: Open University Press.

Ramsden, P., M. Prosser, K. Trigwell, and E. Martin. 2007. “University Teachers' Experiences of Academic Leadership and Their Approaches to Teaching." Learning and Instruction 17 (2): 140-55.

Rotter, J. B. 1954. Social Learning and Clinical Psychology. New York: Prentice Hall.

Samuelowicz, K., and J. D. Bain. 1992. "Conceptions of Teaching Held by Academic Teachers." Higher Education 24 (1): 93-111.

Sandberg, J. 1997. “Are Phenomenographic Results Reliable?” Higher Education Research and Development 16 (2): 203-12.

Sandberg, J. 2000. "Understanding Human Competence at Work: An Interpretative Approach." Academy of Management Journal 43 (1): 9-25.

Shreeve, A. 2010. "A Phenomenographic Study of the Relationship between Professional Practice and Teaching Your Practice to Others." Studies in Higher Education 35 (6): 691-703.

Sitkin, S. B., and L. R. Weingart. 1995. "Determinants of Risky Decision-Making Behavior: A Test of the Mediating Role of Risk Perceptions and Propensity." Academy of Management Journal 38 (6): 1573-92.

Strathern, M. 1997. “'Improving Ratings': Audit in the British University System.” European Review 5 (3): 305-21.

Trigwell, K. 2012. "Relations between Teachers' Emotions in Teaching and Their Approaches to Teaching in Higher Education." Instructional Science 40 (3): 607-21.

von Neumann, J., and O. Morgenstern. 1944. Theory of Games and Economic Behavior. Princeton: Princeton University Press.

Winter, R. 2009. “Academic Manager or Managed Academic? Academic Identity Schisms in Higher Education." Journal of Higher Education Policy and Management 31 (2): 12131.

Wright, A., J. P. Murray, and P. Geale. 2007. "A Phenomenographic Study of What It Means to Supervise Doctoral Students." Academy of Management Learning and Education 6 (4): 458-74.

Ylijoki, O.-H., and J. Ursin. 2013. "The Construction of Academic Identity in the Changes of Finnish Higher Education.” Studies in Higher Education 38 (8): 1135-49.

Zinn, J. O. 2015. “Towards a Better Understanding of Risk-Taking: Key Concepts, Dimensions and Perspectives." Health, Risk and Society 17 (2): 99-114. 
Zoller, F. A., E. Zimmerling, and R. Boutellier. 2014. "Assessing the Impact of the Funding Environment on Researchers' Risk Aversion: The Use of Citation Statistics.” Higher Education 68 (3): 333-45. 
Table 1. Outcome space for variation in faculty experiences of academic risk taking.

\begin{tabular}{|c|c|c|c|c|c|c|c|}
\hline $\begin{array}{l}\text { External } \\
\text { horizon }\end{array}$ & $\begin{array}{l}\text { Category of } \\
\text { description }\end{array}$ & \multicolumn{2}{|c|}{ Internal horizon } & \multicolumn{4}{|c|}{ Dimension of variation } \\
\hline $\begin{array}{l}\text { The perceptual } \\
\text { boundary }\end{array}$ & $\begin{array}{l}\text { The qualitative } \\
\text { way in which } \\
\text { academic risk } \\
\text { taking is } \\
\text { experienced }\end{array}$ & $\begin{array}{l}\text { What is } \\
\text { present in the } \\
\text { focus of } \\
\text { awareness }\end{array}$ & $\begin{array}{l}\text { What is absent } \\
\text { from the focus } \\
\text { of awareness }\end{array}$ & $\begin{array}{c}\text { Determinants } \\
\text { (the motivations } \\
\text { behind risk } \\
\text { behaviours) }\end{array}$ & $\begin{array}{l}\text { Outcomes } \\
\text { (the perceived } \\
\text { consequences of } \\
\text { risk taking) }\end{array}$ & $\begin{array}{c}\text { Coping } \\
\text { mechanisms } \\
\text { (the set of risk } \\
\text { management } \\
\text { practices) }\end{array}$ & $\begin{array}{l}\text { Feelings } \\
\text { (the affective } \\
\text { experience of } \\
\text { academic risk } \\
\text { taking) }\end{array}$ \\
\hline Individual & $\begin{array}{l}\text { 1: Experimenting } \\
\text { with things }\end{array}$ & $\begin{array}{l}\text { Faculty } \\
\text { knowledge } \\
\text { and skills }\end{array}$ & $\begin{array}{l}\text { Progress of the } \\
\text { discipline }\end{array}$ & $\begin{array}{l}\text { Primarily internal, but } \\
\text { partial influence of the } \\
\text { organisational context }\end{array}$ & $\begin{array}{l}\text { Personal learning } \\
\text { to lower student } \\
\text { satisfaction }\end{array}$ & $\begin{array}{l}\text { Acquisition of } \\
\text { task-related } \\
\text { skills }\end{array}$ & $\begin{array}{l}\text { Sense of } \\
\text { achievement to } \\
\text { anxiety }\end{array}$ \\
\hline \multirow[t]{2}{*}{$\begin{array}{l}\text { University } \\
\text { community }\end{array}$} & $\begin{array}{l}2: \text { Being } \\
\text { intellectually } \\
\text { opportunistic }\end{array}$ & $\begin{array}{l}\text { Academics' } \\
\text { capabilities } \\
\text { and } \\
\text { reputation }\end{array}$ & $\begin{array}{l}\text { Student and } \\
\text { societal needs }\end{array}$ & $\begin{array}{l}\text { Primarily internal, but } \\
\text { partial influence of the } \\
\text { organisational and } \\
\text { higher education } \\
\text { contexts }\end{array}$ & $\begin{array}{l}\text { Establishing } \\
\text { oneself to } \\
\text { working in an } \\
\text { overtraded market }\end{array}$ & $\begin{array}{l}\text { Development of } \\
\text { the ability to } \\
\text { identify } \\
\text { opportunities }\end{array}$ & $\begin{array}{l}\text { Self-fulfilment to } \\
\text { sense of } \\
\text { insecurity }\end{array}$ \\
\hline & $\begin{array}{l}\text { 3: Challenging } \\
\text { conventional } \\
\text { wisdom }\end{array}$ & $\begin{array}{l}\text { Student } \\
\text { learning and } \\
\text { disciplinary } \\
\text { advancement }\end{array}$ & $\begin{array}{l}\text { Commitment to } \\
\text { societal goals }\end{array}$ & $\begin{array}{l}\text { Primarily internal, but } \\
\text { significant influence of } \\
\text { the organisational and } \\
\text { higher education } \\
\text { contexts }\end{array}$ & $\begin{array}{l}\text { Enhanced student } \\
\text { learning to } \\
\text { disengagement } \\
\text { from others }\end{array}$ & $\begin{array}{l}\text { Anticipation of } \\
\text { external } \\
\text { expectations }\end{array}$ & $\begin{array}{l}\text { Excitement to } \\
\text { fear }\end{array}$ \\
\hline Society at large & $\begin{array}{l}\text { 4: Doing what } \\
\text { you feel is right }\end{array}$ & $\begin{array}{l}\text { Contribution } \\
\text { to the } \\
\text { common } \\
\text { good }\end{array}$ & $\begin{array}{l}\text { Faculty skills } \\
\text { and capabilities }\end{array}$ & $\begin{array}{l}\text { Primarily internal, but } \\
\text { significant influence of } \\
\text { the organisational, } \\
\text { higher education and } \\
\text { societal contexts }\end{array}$ & $\begin{array}{l}\text { Making an impact } \\
\text { to limited career } \\
\text { progression }\end{array}$ & $\begin{array}{l}\text { Understanding } \\
\text { of institutional } \\
\text { requirements }\end{array}$ & $\begin{array}{l}\text { Sense of reward } \\
\text { to helplessness }\end{array}$ \\
\hline
\end{tabular}


Table 2. Summary of variation in faculty understandings of academic risk taking.

\begin{tabular}{llll}
\hline $\begin{array}{l}\text { Orientation } \\
\text { (the outer limits of } \\
\text { awareness) }\end{array}$ & $\begin{array}{c}\text { Content } \\
\text { (what faculty view as } \\
\text { the essence of } \\
\text { academic risk taking) }\end{array}$ & $\begin{array}{c}\text { Intention } \\
\text { (the purpose of engaging } \\
\text { in risk behaviours) }\end{array}$ & $\begin{array}{c}\text { Strategy } \\
\text { (how academic } \\
\text { risk taking is } \\
\text { enacted) }\end{array}$ \\
\hline Individual perspective & $\begin{array}{l}\text { Venturing into } \\
\text { unfamiliar areas }\end{array}$ & $\begin{array}{l}\text { Extending personal } \\
\text { knowledge and skills }\end{array}$ & $\begin{array}{l}\text { Stretching oneself } \\
\text { professionally }\end{array}$ \\
$\begin{array}{l}\text { University community } \\
\text { perspective }\end{array}$ & $\begin{array}{l}\text { Searching for new } \\
\text { opportunities }\end{array}$ & $\begin{array}{l}\text { Enhancing academic } \\
\text { standing within the wider } \\
\text { community }\end{array}$ & $\begin{array}{l}\text { Departing from } \\
\text { the status quo }\end{array}$ \\
Society perspective & $\begin{array}{l}\text { Disrupting settled } \\
\text { expectations }\end{array}$ & $\begin{array}{l}\text { Making a contribution to } \\
\text { society }\end{array}$ & $\begin{array}{l}\text { Pursuing personal } \\
\text { ideals and values }\end{array}$ \\
\hline
\end{tabular}

